\title{
Extract of seaweed Gracilaria verrucosa as immunostimulant to controlling white spot disease in Pacific white shrimp Litopenaeus vannamei
}

\section{Ekstrak rumput laut Gracilaria verrucosa sebagai imunostimulan untuk pengendalian penyakit white spot pada udang vaname Litopenaeus vannamei}

\author{
Aminatul Zahra, Sukenda Sukenda*, Dinamella Wahjuningrum \\ Department of Aquaculture, Faculty of Fisheries and Marine Science, Bogor Agricultural University \\ Campus IPB Dramaga Bogor, West Java, Indonesia 16680 \\ *E-mail: sukenda67@gmail.com
}

\begin{abstract}
This experiment was conducted to examine effect of Gracilaria verrucosa extract in diet with different dosages to enhance immune response and resistance against white spot syndrome virus (WSSV) in the Pacific white shrimp. The experiment consisted of six treatments in three replicates respectively, namely $\mathrm{K}$ - (without extract), $\mathrm{K}+$ (without extract + infected WSSV), A ( $2 \mathrm{~g} / \mathrm{kg}$ of feed + infected WSSV), B ( $\mathrm{g} / \mathrm{kg}$ of feed + infected WSSV), $\mathrm{C}(4 \mathrm{~g} / \mathrm{kg}$ of feed + infected WSSV), and D (5 g/kg of feed + infected WSSV). Pacific white shrimp with initial body weight of $6.07 \pm 0.10 \mathrm{~g}$ were reared in the aquarium $\left(60 \times 30 \times 30 \mathrm{~cm}^{3}\right)$ with density of 10 shrimps/aquarium. $G$. verrucosa was extracted with ethyl acetate. Pacific white shrimp had been fed medicated feed three times daily $3 \%$ at satiation for 14 days. At 15th days, white shrimp were challenged with WSSV at $0.1 \mathrm{~mL} / \mathrm{shrimp}$ intramuscularly. The results showed that the immune response shrimp (total hemocyte count, phagocytic activity, respiratory burst, and phenoloxidase activity) fed medicated feed increased significantly compared to positive and negative controls. The best relative percent survival post-challenge test was at $4 \mathrm{~g} / \mathrm{kg}$ dose of $G$. verrucosa, i.e $41.07 \pm 3.09 \%$. Confirmation of WSSV using PCR showed that shrimps (A, B, C, D, and K+) were positively infected by WSSV. It was concluded that $4 \mathrm{~g} / \mathrm{kg}$ dose of $G$. verrucosa gave the best result to enhance immune response and resistance to WSSV infection.
\end{abstract}

Keywords: seaweed, Gracilaria verrucosa, immunostimulant, Pacific white shrimp, WSSV

\begin{abstract}
ABSTRAK
Penelitian ini bertujuan untuk menguji pengaruh pemberian ekstrak Gracilaria verrucosa melalui pakan dengan dosis yang berbeda untuk meningkatkan imunitas dan resistensi udang vaname terhadap serangan white spot syndrome virus (WSSV). Penelitian ini terdiri atas enam perlakuan dan masing-masing tiga ulangan, yaitu K(tanpa ekstrak), K+ (tanpa ekstrak + infeksi WSSV), A ( $\mathrm{g} / \mathrm{kg}$ pakan + infeksi WSSV), B (3 g/kg pakan + infeksi WSSV), C (4 g/kg pakan + infeksi WSSV), dan D ( $5 \mathrm{~g} / \mathrm{kg}$ pakan + infeksi WSSV). Udang vaname dengan bobot $6,07 \pm 0,10 \mathrm{~g}$ dipelihara dalam akuarium dengan ukuran $\left(60 \times 30 \times 30 \mathrm{~cm}^{3}\right)$ dengan padat tebar 10 ekor/akuarium. Udang diberi pakan perlakuan secara at satiation sebanyak tiga kali sehari selama 14 hari. Pada hari ke-15 diuji tantang dengan WSSV pada dosis $0,1 \mathrm{~mL} /$ ekor secara intramuskular. Hasil penelitian menunjukkan bahwa respons imun udang (total hemosit, aktivitas fagositik, respiratory burst, dan aktivitas fenoloksidase) yang diberi pakan mengandung ekstrak G. verrucosa mengalami peningkatan signifikan dibanding perlakuan kontrol positif maupun negatif. Relative percent survival terbaik pasca uji tantang pada perlakuan C ( $4 \mathrm{~g} / \mathrm{kg})$, yaitu $41,07 \pm 3,09 \%$. Konfirmasi WSSV dengan menggunakan PCR menunjukkan hasil bahwa udang (A, B, C, D, and K+) positif terinfeksi WSSV. Disimpulkan bahwa dosis ekstrak G. verrucosa $4 \mathrm{~g} / \mathrm{kg}$ pakan memberikan hasil terbaik untuk meningkatkan respons imun pada udang vaname dan resistensi terhadap WSSV.
\end{abstract}

Kata kunci: rumput laut, Gracilaria verrucosa, imunostimulan, udang vaname, WSSV 


\section{INTRODUCTION}

A disease that often strikes Pacific white shrimp is white spot, which is caused by white spot syndrome virus (WSSV). This virus can lead to total mortality $(100 \%)$ within 210 days post outbreak (Wang et al., 2007). An effort to prevent WSSV strike in shrimp farming without altering neither the consumer health nor the environment is the supplementation of immunostimulant from plant materials that are environmentally friendly. Immunostimulant is a biological or synthesized compound that can induce the non-specific immune system of the shrimp (Muiswinkel \& Pilarczyk, 2015).

A natural plant material that could be evaluated as a safe and environmentally friendly immunostimulant material is seaweed Gracilaria verrucosa. $G$. verrucosa can be used as immunostimulant due to the fact that it contains polysaccharide (Anggadiredja et al., 2006). Polysaccharides from seaweed can stimulate the non-specific immune system, i.e. phagocytic activity and respiratory burst through a mechanism of interactions with the surface of the receptors (receptor-mediated). Phyto-chemical test results of solid G. verrucosa seaweed extract revealed that it contained chemical compounds such as alkaloid, flavonoid, and steroid (Siregar et al., 2012).

Wongprasert et al. (2013) stated that sulfated galactan, isolated from G. fisheri at a dose of 100$200 \mu \mathrm{g} / \mathrm{mL}$, can increase both the immune system and the antiviral activity of shrimp infected by WSSV. Sirirustananun et al. (2011) demonstrated that the supplementation of $G$. Tenuistipitata in shrimp feed, at a dose of $0.5-2.0 \mathrm{~g} / \mathrm{kg}$ for 14 days, can increase the immune system of shrimp infected by WSSV. According to Jasmanindar (2009), the use of $G$. verrucosa extracts at a dose of $50 \mu \mathrm{g} / \mathrm{g}$ shrimp weight in increasing the defense system of Pacific white shrimp resulted in an increase in Pacific white shrimp resistance against Vibrio harveyi bacteria, up to $73.3 \%$.

The supplementation of immunostimulant has to pay special attention to the optimal dose to be used (Hai, 2015) due to the fact that a high immunostimulant dose can suppress the defence mechanism, while a low dose could be less effective or not enough to trigger an immune system response. Thus, there is a need to conduct research on the supplementation of G. verrucosa seaweed extract as immunostimulant in Pacific white shrimp feed and determine the optimal dose for feed. The present research was aimed at evaluating different doses of $G$. verrucosa extract in shrimp feed to increasing the immune system of Pacific white shrimp.

\section{MATERIALS AND METHODS}

\section{Research procedures}

Extraction of seaweed G. verrucosa

G. verrucosa at 1.5 months old of age, were collected from a seaweed farming in Muara Gembong, Bekasi. The seaweed was washed with both seawater and freshwater to dispose of salt, microorganisms, and other unwanted materials. The cleaned seaweed was then air dried without exposure to direct sunlight. Afterward, seaweed was finely ground and sieved by mean of a fine sieve (60 mesh size). Extraction was performed by adding ethyl acetate solvent at a ratio of 1:5 (w/v), shaking for 24 hours, precipitating, and finally filtering. The obtained filtrate was then evaporated using a vacuum rotary evaporator at a temperature of $50{ }^{\circ} \mathrm{C}$ to acquire a thick extract.

\section{Feed preparation}

$G$. verrucosa extract, based on the doses of each treatment previously determined, was dissolved in a $100 \mathrm{~mL}$ of distilled water that was previously mixed with egg white as a binder at a concentration of $2 \%$. The obtained solution was then evenly mixed with commercial shrimp feed and dried in an oven at $37^{\circ} \mathrm{C}$.

\section{Container preparation}

Eighteen aquariums $\left(60 \times 30 \times 30 \mathrm{~cm}^{3}\right)$ were used as rearing containers in the present study and equipped with aerator, aeration hose, and aeration stones. All the aquariums were sterilized using $100 \mathrm{mg} / \mathrm{L}$ calcium hypochlorite $\mathrm{Ca}\left(\mathrm{CIO}_{2}\right)$ for 24 hours, rinsed with clean water and dried prior to usage. Sea water, used for rearing, was also sterilized using calcium hypochlorite $\mathrm{Ca}\left(\mathrm{CIO}_{2}\right)$ at a concentration of $30 \mathrm{ppm}$ in the storage tank. Aquariums were filled with sterile seawater at a height of $20 \mathrm{~cm}$ and aerated for 24 hours.

\section{Shrimp for experiment}

The shrimp used in the present study was Litopenaeus vannamei that was brought from a shrimp farm located in Bakauheni, Lampung. Shrimp at an average body weight of $6.07 \pm 0.10 \mathrm{~g} /$ shrimp were used and acclimatized in fiber tanks for two weeks at $28^{\circ} \mathrm{C}$. Shrimp were stocked at a density of 10 shrimp/aquarium. 


\section{Evaluation of G. verrucosa extract dose in shrimp} feed

A completely randomized design was used in the present research. G. verrucosa extract doses in shrimp feed consisted of six treatments (with three replicates each) as follows: K- (without $G$. verrucosa extract), $\mathrm{K}+$ (without $G$. verrucosa extract + WSSV infection), A (2 $\mathrm{g} / \mathrm{kg}$ feed + WSSV extract), B ( $3 \mathrm{~g} / \mathrm{kg}$ feed + WSSV infection), $\mathrm{C}(4 \mathrm{~g} / \mathrm{kg}+\mathrm{WSSV}$ infection), and D ( $5 \mathrm{~g} / \mathrm{kg}$ feed + WSSV infection). Shrimp were fed on a $32 \%$ protein feed (containing G. verrucosa according to each treatment) at satiation and feeding was performed 3 times a day for 14 days. After day 14, shrimp were fed on commercial feed (without $G$. verrucosa extract) and challenge test was carried out on day 15.

\section{WSSV infection}

Shrimp used for the infection test were those that were already infected by WSSV and showed clinical symptoms such as white spots on the carapace (which was confirmed using PCR). As much as one gram of infected shrimp organ was collected, finely ground, and dissolved in a $9 \mathrm{~mL}$ PBS (phosphate buffered saline) solution. Afterward, the solution was rotated using a centrifuge, first at a speed of $3000 \mathrm{rpm}$ for 30 minutes, and finally at a speed of $8000 \mathrm{rpm}$ for 20 minutes. The acquired supernatant was filtered using a filter holder with a filtering paper $(0.45$ $\mu \mathrm{m})$ and a syringe. WSSV infection in Pacific white shrimp was done by injection and the infection test was carried out by intramuscularly injection ( $3^{\text {rd }}$ segment of the abdomen) with 0.1 $\mathrm{mL}$ of virus solution that was diluted until $10^{-3}$ in a PBS solution. Otherwise, the negative control shrimp were injected with PBS only (Yao et al., 2015).

\section{Hemolymph collection}

Hemolymph, $0.2 \mathrm{~mL}$, was collected at the base of the swimming leg of the shrimp using a $1 \mathrm{~mL}$ syringe (previously filled with $0.4 \mathrm{~mL}$ of Na-citrate anticoagulant) and homogenized by a hand shake to shape number 8 for 5 minutes. Hemolymph was collected in order to determine parameters such as total hemocytes (THC), phagocytic activity (PA), phenoloxidase activity (PO), and respiratory burst (RB). Data collection on parameters was done by gathering hemolymph and monitoring shrimp mortality in each replicate pre-treatment, 14 days post treatment and 3 days post challenge test.

\section{Tested parameters}

\section{WSSV presence confirmation}

Virus inspection with the polymerase chain reaction (PCR) method was performed to confirm the presence of WSSV virus in test shrimp that was done prior to treatment and on day 10 post infection.

\section{Total hemocytes}

A drop of hemolymph solution was placed on a hemocytometer and the total cell $/ \mathrm{mm}^{3}$ counted. The total hemocytes were determined using the following formula:

\section{Total hemocytes $\left(\right.$ cell $\left./ \mathrm{mm}^{3}\right)=$} counted cell $\times$ dilution factor box volume

\section{Phagocytic activity}

Shrimp hemolymph, $0.1 \mathrm{~mL}$, was placed into a micro plate, evenly mixed with $25 \mu \mathrm{L}$ of Staphylococcus aureus $\left(10^{7} \mathrm{CFU} / \mathrm{mL}\right)$ bacteria, and incubated for 20 minutes. Afterward, $5 \mu \mathrm{L}$ was dropped on a preparation glass to form preparation pads. Next, the preparations were fixed with absolute methanol for 5 minutes and stained with Giemsa (10\%) for 15 minutes. Phagocytic activity was measured based on the percentage of phagocytic cells that carried out phagocytic activity.

\section{Phagocytic activity $(\%)=$}

$\sum$ Phagocytizing cell $/ \sum$ Phagocytic cell $\times 100$

\section{Phenoloxidase activity (PO)}

Phenoloxidase activity was measured using a spectrophotometer to record the formation of dopachrome that results from L-dihydroxyphenylalanine (L-DOPA). The diluted hemolymph was then centrifuged at 700 $\times g$ and a temperature of $4{ }^{\circ} \mathrm{C}$ for 20 minutes. The supernatant was disposed and the pellet rinsed, slowly re-suspended in cacodylate-citrate buffer (0.01 M sodium cacodylate; $0.45 \mathrm{M}$ sodium chloride; 0,10 M trisodium citrate; $\mathrm{pH} 7$ ), and $100 \mu \mathrm{L}$ of aliquot incubated with $50 \mu \mathrm{L}$ trypsin $(1$ $\mathrm{mg} / \mathrm{mL}$ ) as activator for 10 minutes at $25-26{ }^{\circ} \mathrm{C}$. Afterward, $50 \mu \mathrm{L}$ L-DOPA was added and $800 \mu \mathrm{L}$ cacodylate buffer was then added 5 minutes later. Optical density at $490 \mathrm{~nm}$ was measured using a U-2000 Hitachi spectrophotometer. The optical density of phenoloxidase activity in shrimp was expressed in a form of dopachrome in a $50 \mu \mathrm{L}$ hemolymph. 


\section{Respiratory burst $(R B)$}

Respiratory burst from hemocytes was measured based on NBT (nitroblue tetrazolium) reduction as superoxide anion $\left(\mathrm{O}_{2}^{-}\right)$size. Hemolymph-anticoagulant solution $(50 \mu \mathrm{L})$ solution was incubated for 30 minutes at room temperature, centrifuged at a speed of $3500 \mathrm{rpm}$ for 20 minutes, and the supernatant disposed of. A $100 \mu \mathrm{L}$ of NBT was added to the HBSS (hank's buffered salt solution at a concentration of $0.3 \%$ ) solution and let to rest for 2 hours at room temperature. Afterward, the solution was centrifuged at $3500 \mathrm{rpm}$ for 10 minutes, the supernatant disposed of, and a $100 \mu \mathrm{L}$ of absolute methanol added and centrifuged at $3500 \mathrm{rpm}$ for 10 minutes (supernatant was disposed). The formed pellet was then rinsed twice with $70 \%$ methanol. Afterward, $120 \mu \mathrm{L} \mathrm{KOH} \mathrm{(2M)} \mathrm{and}$ $140 \mu \mathrm{L}$ DMSO (dimethylsulfoxide) were added to dissolve the pellet. The dissolved pellet was then put into a microplate to measure the optical density (OD) using a microplate reader with a wavelength of $630 \mathrm{~nm}$. RB was declared as the reduction of NBT per $10 \mu \mathrm{L}$ hemolymph.

\section{Mortality}

Shrimp mortality was determined 10 days post challenge test with WSSV and calculated using the following formula:

$$
\mathrm{MR}=\mathrm{Mt} / \mathrm{Mo} \times 100
$$

Note:

MR = mortality $(\%)$

Mt = the number of the dead shrimp at the final observation (individuals)

Mo $=$ the number of the dead shrimp at the initial observation (individuals)

\section{Relative percent survival (RPS)}

The relative percent survival was calculated to determine the effectiveness of the supplemented immunostimulant in Pacific white shrimp. RPS was calculated on day 10 post challenge test using the following formula:

$$
\mathrm{RPS}=[1-(\mathrm{Mv} / \mathrm{Mc})] \times 100
$$

Note:

RPS = Relative percent survival (\%)

$\mathrm{Mv} \quad=$ Mortality of treatment $(\%)$

$\mathrm{Mc} \quad=$ Mortality of control (\%)

\section{Data analysis}

Data analysis was carried out using two methods, i.e. ANOVA (SPSS 17) an interval of confidence of $95 \%(a=0.05)$ and descriptive analysis. ANOVA was used to analyze total hemocytes, phagocytic activity, phenoloxidase activity, respiratory burst, mortality, and RPS. An ANOVA test was followed by Duncan's posthoc comparison test if differences were found. Meanwhile, a descriptive analysis was used on PCR data.

\section{RESULTS AND DISCUSSION}

\section{Results}

Total hemocytes

Total hemocytes post G. verrucosa extract supplementation experienced rises in treatments $\mathrm{A}, \mathrm{B}, \mathrm{C}$, and $\mathrm{D}$, which were significantly different $(\mathrm{P}<0.05)$ compared to control. The highest total hemocytes were observed in treatment C, post G. verrucosa extract supplementation and significantly differed $(\mathrm{P}<0.05)$ to other treatments. Total hemocytes post challenge test was significantly higher in treatments $\mathrm{A}, \mathrm{B}$, and $\mathrm{C}$ compared to control, but that of treatment $\mathrm{D}$ did not significantly $(\mathrm{P}>0.05)$ differ to that of $\mathrm{K}+$. Total hemocytes at the initial, before, and after challenge test is presented in Figure 1.

\section{Phagocytic activity}

Phagocytic activity experienced an increase post $G$. verrucosa extract supplementation and challenge test. The phagocytic activity, prior to challenge test, in treatments $\mathrm{A}, \mathrm{B}, \mathrm{C}$, and $\mathrm{D}$ significantly differed $(\mathrm{P}<0.05)$ to control. Phagocytic activity in treatment $\mathrm{A}, \mathrm{B}$, and $\mathrm{C}$ was significantly different $(\mathrm{P}<0.05)$ to control, while that of treatment $\mathrm{D}$ did not significantly differ $(\mathrm{P}>0.05)$ to control. Treatment $\mathrm{C}$ had the highest phagocytic activity both before and after the challenge test and significantly differed to other treatments $(\mathrm{P}<0.05)$. Phagocytic activity at the initial, before, and after the challenge test is presented in Figure 2.

\section{Phenoloxidase activity ( $P O)$}

Phenoloxidase activity encountered increments before and after the challenge test. The activity in treatments $\mathrm{A}, \mathrm{B}$, and $\mathrm{C}$ significantly $(\mathrm{P}<0.05)$ differed to control both before and after challenge test, while the phenoloxidase activity in treatment $\mathrm{D}$ did not differ $(\mathrm{P}>0.05)$ to that of $\mathrm{K}+$. The highest phenoloxidase activity, both 
before and after challenge test, was observed in treatment $\mathrm{C}$ which was significantly different to other treatments $(\mathrm{P}<0.05)$. Phenoloxidase activity at the initial, before, and after the challenge test is presented in Figure 3.

\section{Respiratory burst (RB)}

Respiratory burst, before and after the challenge test, experienced rises compared to the one at the initial of the measurement. Respiratory burst in treatments $\mathrm{A}, \mathrm{B}, \mathrm{C}$, and D before and after the challenge test was significantly different $(\mathrm{P}<0.05)$ to control. Treatment $\mathrm{C}$ had the highest respiratory burst (before and after challenge test) which was significantly different $(\mathrm{P}<0.05)$ to control and treatment $\mathrm{D}$; while treatment $\mathrm{A}$ and $\mathrm{B}$ did not significantly differ $(\mathrm{P}>0.05)$. Respiratory burst at the initial, before, and after challenge test is presented in Figure 4.

\section{WSSV confirmation}

The confirmation of WSSV presence in experimental shrimp was evaluated by mean of PCR analysis. Samples were collected from treatment that showed clinical symptoms (A, B, $\mathrm{C}, \mathrm{D}$, and $\mathrm{K}+$ ) such redness of the body, pale hepatopancreas, empty intestine, and treatment $\mathrm{K}$ - that was injected with PBS. The results showed that 5 samples (samples A, B, C, D, and $\mathrm{K}+$ ) were positively infected by WSSV, while treatment Kdid not show any symptoms of WSSV infection. The confirmation test results with nested PCR are presented in Figure 5.

\section{Mortality and relative percent survival (RPS)}

The highest mortality post challenge test with WSSV was observed in positive control, which was significantly different $(\mathrm{P}<0.05)$ to those of treatments $\mathrm{A}, \mathrm{B}$, and $\mathrm{C}$. the highest relative

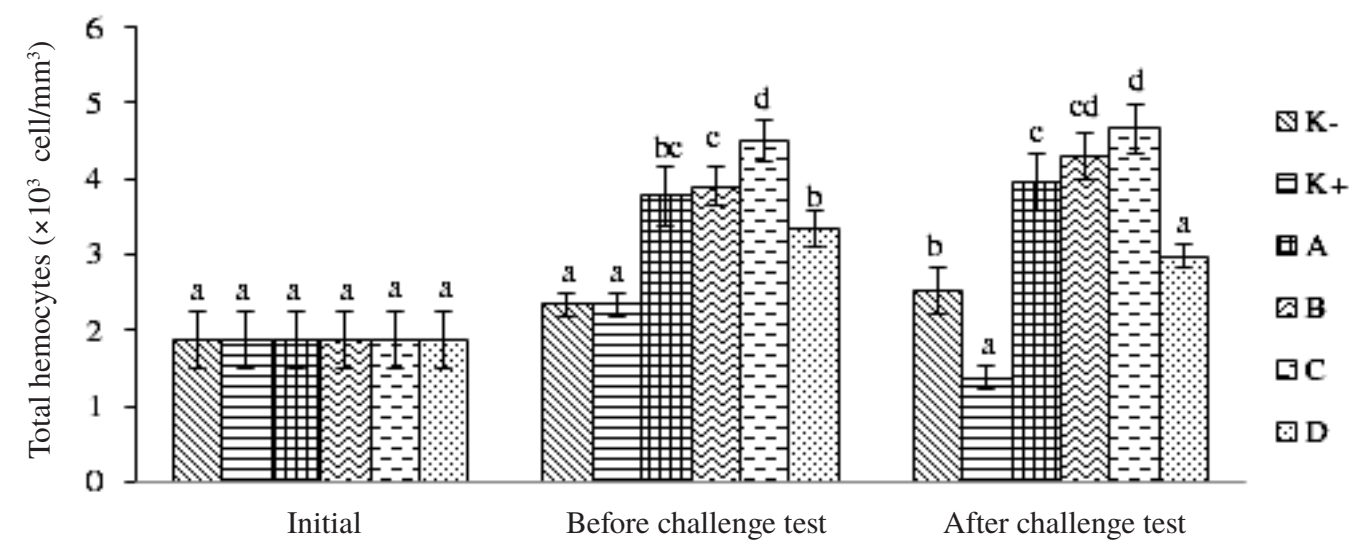

Figure 1. Total hemocytes (THC) of L. vannamei shrimp at the initial, before challenge test (at the end of $G$. verrucosa extract supplementation test), and after challenge test. Different letters at the top of each bar showed significant differences among treatments $(\mathrm{P}<0.05)$. Description: $\mathrm{K}-$ : negative control; $\mathrm{K}+$ : positive control; A: $G$. verrucosa extract at $2 \mathrm{~g} / \mathrm{kg}$ feed; B: G. verrucosa extract at $3 \mathrm{~g} / \mathrm{kg}$ feed; C: G. verrucosa extract at $4 \mathrm{~g} / \mathrm{kg}$ feed; D: G. verrucosa extract at $5 \mathrm{~g} / \mathrm{kg}$ feed.

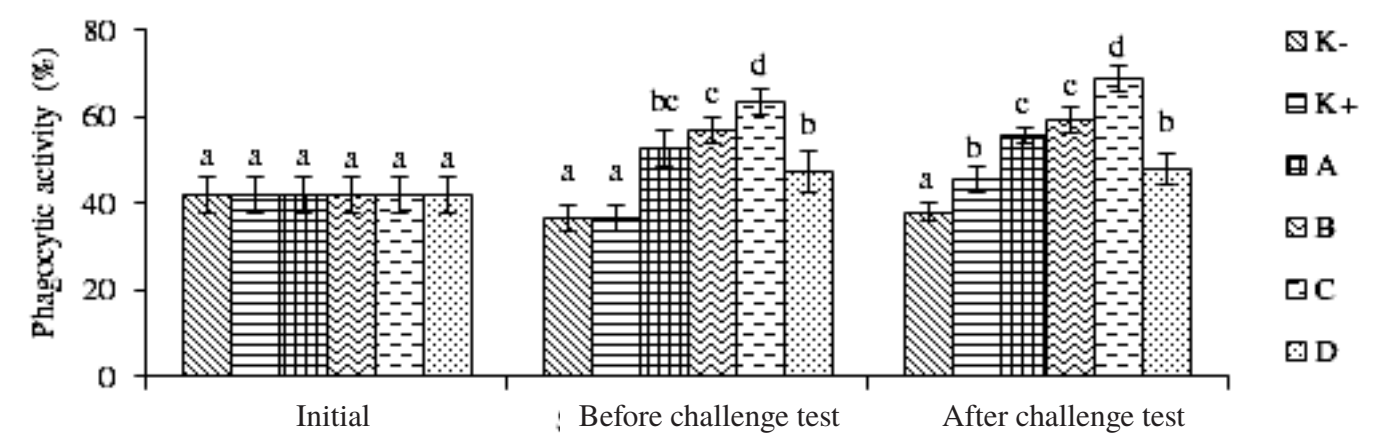

Figure 2. Phagocytic activity of L. vannamei shrimp at the initial, before challenge test (at the end of G. verrucosa extract supplementation test), and after the challenge test. Different letters at the top of each bar showed significant differences among treatments $(\mathrm{P}<0.05)$. Description: $\mathrm{K}-$ : negative control; $\mathrm{K}+$ : positive control; A: G. verrucosa extract at $2 \mathrm{~g} / \mathrm{kg}$ feed; B: G. verrucosa extract at $3 \mathrm{~g} / \mathrm{kg}$ feed; C: G. verrucosa extract at $4 \mathrm{~g} / \mathrm{kg}$ feed; D: G. verrucosa extract at $5 \mathrm{~g} / \mathrm{kg}$ feed. 


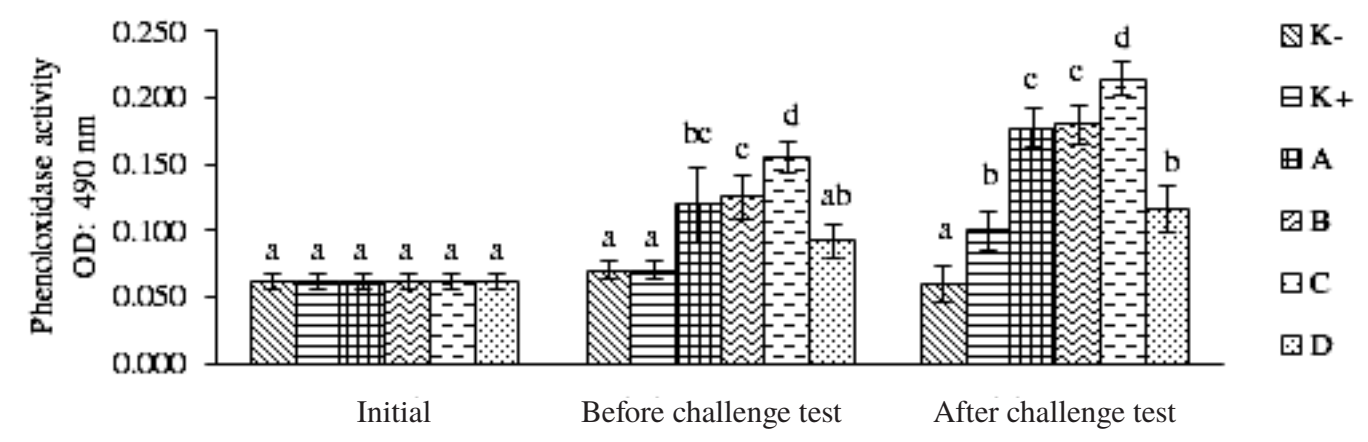

Figure 3. Phenoloxidase activity of L. vannamei shrimp at the initial, before challenge test (at the end of $G$. verrucosa extract supplementation test), and after the challenge test. Different letters at the top of each bar showed significant differences among treatments $(\mathrm{P}<0.05)$. Description: $\mathrm{K}-:$ negative control; $\mathrm{K}+$ : positive control; A: $G$. verrucosa extract at $2 \mathrm{~g} / \mathrm{kg}$ feed; B: G. verrucosa extract at $3 \mathrm{~g} / \mathrm{kg}$ feed; C: G. verrucosa extract at $4 \mathrm{~g} / \mathrm{kg}$ feed; D: G. verrucosa extract at $5 \mathrm{~g} / \mathrm{kg}$ feed.

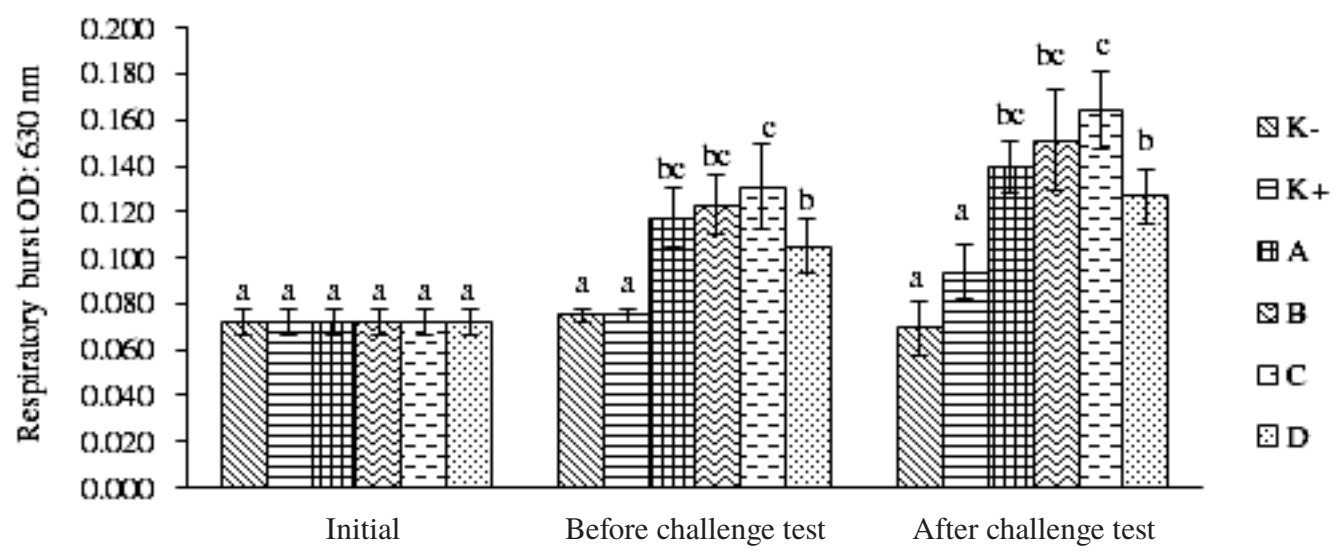

Figure 4. Respiratory burst of L. vannamei shrimp at the initial, before challenge test (at the end of G. verrucosa extract supplementation test), and after the challenge test. Different letters at the top of each bar showed significant differences among treatments $(\mathrm{P}<0.05)$. Description: $\mathrm{K}-$ : negative control; $\mathrm{K}+$ : positive control; $\mathrm{A}$ : G. verrucosa extract at $2 \mathrm{~g} / \mathrm{kg}$ feed; B: G. verrucosa extract at $3 \mathrm{~g} / \mathrm{kg}$ feed; C: G. verrucosa extract at $4 \mathrm{~g} / \mathrm{kg}$ feed; D: G. verrucosa extract at $5 \mathrm{~g} / \mathrm{kg}$ feed.

percent survival (RPS) of Pacific white shrimp post challenge test with WSSV was observed in treatment $\mathrm{D}$ and significantly differed $(\mathrm{P}<0.05)$ to other treatments. Mortality and relative percent survival of Pacific white shrimp post challenge test with WSSV are presented in Table 1.

\section{Discussion}

The results of the present study showed that $G$. verrucosa extract supplementation can increase the total hemocytes in shrimp. Hemocyte is a cell that plays an important (main) role in crustacean immune defense in both cellular and humoral levels (Xu et al., 2014). A change in total hemocytes is an indicator of not only stress, but health status of the shrimp. In addition, hemocyte is also involved in the synthesis and release of important molecules such as $\alpha$-2-macroglobulin $(\alpha 2 \mathrm{M})$, agglutinin and antibacterial peptide as body defense reaction in shrimp (Rodriguez \& Moullac, 2000).

The increase in total hemocytes (Figure 1) occurred in shrimp fed on $G$. verrucosa extract in treatments A ( $2 \mathrm{~g} / \mathrm{kg}$ feed), B ( $3 \mathrm{~g} / \mathrm{kg}$ feed), C (4 $\mathrm{g} / \mathrm{kg}$ feed), and $\mathrm{D}$ ( $5 \mathrm{~g} / \mathrm{kg}$ feed $)$, and the mentioned increment was significantly $(\mathrm{P}<0.05)$ different to control. This indicated that $G$. verrucosa extract had the ability to stimulate hemocyte cells formation in shrimp. In a research conducted by Jasmanindar (2009), the supplementation of $G$. verrucosa extract in shrimp was able to increase the total hemocytes. Increments in total hemocytes post challenge test occurred in treatments A ( $2 \mathrm{~g} / \mathrm{kg}$ feed), B (3 g/kg feed), C ( $4 \mathrm{~g} / \mathrm{kg}$ feed), while treatments D (5 $\mathrm{g} / \mathrm{kg}$ feed) and the positive control experienced drops. The mentioned increment in total hemocytes indicated that the increase in shrimp body reactive defense 
was a consequence of the presence of extraneous particles that entered the shrimp body i.e. WSSV. The extraneous particle that enters the shrimp body will be recognized by the hemocyte cell receptors, leading to cellular responses such as intracellular signaling cascade, phagocytosis, encapsulation, and nodular aggregation (Rodriguez \& Moullac, 2000).

The increase in total hemocytes in the present study was also followed by a rise in phagocytic activity (Figure 2), which experienced a rising post $G$. verrucosa extract supplementation and challenge test. Phagocytic activities significantly differed $(\mathrm{P}<0.05)$ between $G$. verrucosa extract and control treatments post supplementation and challenge test. A cellular immune response in shrimp in response to foreign objects is through the mechanism of phagocytosing. A gain in phagocytic activity in shrimp also occurred in some research post challenge test as shrimp defense mechanism (Jasmanindar, 2009; Febriani et al., 2013). During the phagocytosis, virus particles will be recognized by receptors on the surface of the cells and swallowed by cells that carry out cytoskeleton re-preparation for phagosome formation. The first formation, phagosome experiences maturation through division and fusion with lysosomes, and become a mature phage-lysosome. The virus that is present in phage-lysosome will be destroyed by low $\mathrm{pH}$ condition, hydrolysis process, and radicals ( $\mathrm{Xu}$ et al., 2014).

Phenoloxidase is an enzyme that plays a role in the process of melanization. This enzyme is produced through proPO (prophenoloxidase) system that is activated by the presence of immunostimulant. Melanization is an important component of the immune defense system of shrimp against pathogens. The activation of proPO system induces the production of melanin,
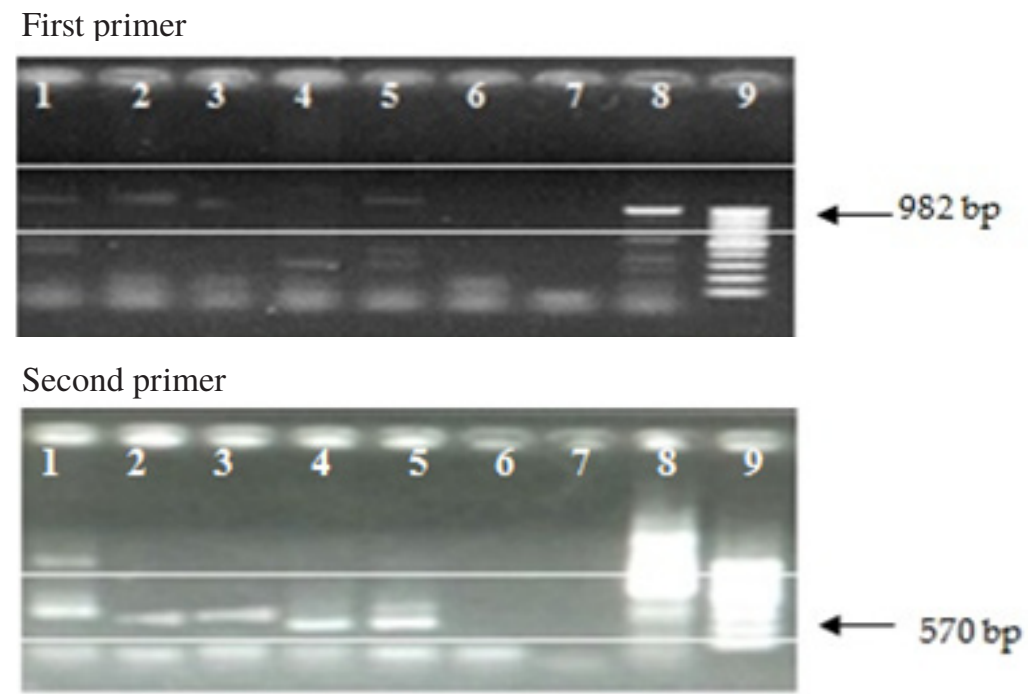

Figure 5. WSSV confirmation with nested PCR. (1) Treatment A, (2) treatment B, (3) treatment C, (4) treatment D, (5) positive control, (6) negative control, (7) negative control, (8) positiv control, (9) marker.

Table 1. Mortality and relative percent survival (RPS) of L. vannamei shrimp at the initial, before challenge test (at the end of G. verrucosa extract supplementation test), and after the challenge test. Different letters at the top of each bar showed significant differences among treatments $(\mathrm{P}<0.05)$. Description: K-: negative control; $\mathrm{K}+$ : positive control; A: G. verrucosa extract at $2 \mathrm{~g} / \mathrm{kg}$ feed; B: G. verrucosa extract at $3 \mathrm{~g} / \mathrm{kg}$ feed; C: $G$. verrucosa extract at 4 $\mathrm{g} / \mathrm{kg}$ feed; D: G. verrucosa extract at $5 \mathrm{~g} / \mathrm{kg}$ feed.

\begin{tabular}{clc}
\hline Treatments & Mortality $(\%)$ & RPS (\%) \\
\hline K+ & $73.33 \pm 5.77 \mathrm{a}$ & - \\
A & $56.67 \pm 5.77 \mathrm{bc}$ & $22.62 \pm 7.43 \mathrm{~b}$ \\
B & $53.33 \pm 5.77 \mathrm{bc}$ & $27.38 \pm 2.06 \mathrm{~b}$ \\
C & $43.33 \pm 5.77 \mathrm{c}$ & $41.07 \pm 3.09 \mathrm{c}$ \\
D & $63.33 \pm 5.77 \mathrm{ab}$ & $13.69 \pm 1.03 \mathrm{a}$ \\
\hline
\end{tabular}


which is a chocolate pigment in charge of various processes, such as the activation of the foreign particle, protect its spread in the host body, and improve cuticle damage. proPO plays an important role in introducing extraneous objects including phagocytic, melanization, cytotoxic reactant production, particle encapsulation, and the formation of nodules and capsules (Amparyup et al., 2013).

Phenoloxidase activity experienced a rise before and after the challenge test. Phenoloxidase activity in treatments A ( $2 \mathrm{~g} / \mathrm{kg}$ feed), B (3 g/kg feed), and $\mathrm{C}(4 \mathrm{~g} / \mathrm{kg}$ feed) significantly differed $(\mathrm{P}<0.05)$ to control, both pre-and post-challenge test. Meanwhile, treatment $\mathrm{D}(5 \mathrm{~g} / \mathrm{kg}$ feed $)$ was not significantly different to $(\mathrm{P}>0.05) \mathrm{K}+$. Rises in the phenoloxidase activity post challenge test were in line with the increments in both total hemocytes and phagocytic activity. Total hemocytes are closely related to proPO stimulation in order to induce phenoloxidase activity. Phenoloxidase activity showed the ability of Pacific white shrimp in recognizing foreign objects that enter the body (Garcia-Carreno et al., 2008) and the presence of defensive activity of the shrimp body (Costa $e t$ al., 2009).

Phagocytosis is the most general response in cell protection. During phagocytosis, the particle or microorganisms enter the cell and form digestive vacuole called phagosome. The deletion mechanism of particles by the phagocytic cell, called respiratory burst, involves the release of degradative enzymes into the phagosome (oxygen dependent killing mechanism) and the production of ROIs (reactive oxygen intermediates) (Rodriguez \& Moullac, 2000).

Respiratory burst, pre-and post-challenge test, experienced increments compared to that at the beginning of the measurement. Respiratory burst in treatments A ( $2 \mathrm{~g} / \mathrm{kg}$ feed $), \mathrm{B}$ ( $3 \mathrm{~g} / \mathrm{kg}$ feed $), \mathrm{C}$ (4 g/kg feed), and D (5 g/kg feed) significantly differed $(\mathrm{P}<0.05)$ to control both before and after the challenge test. The highest respiratory burst was observed in treatment $\mathrm{C}(4 \mathrm{~g} / \mathrm{kg}$ feed $)$ which was significantly $(\mathrm{P}<0.05)$ different to those of control and treatment $\mathrm{D}(5 \mathrm{~g} / \mathrm{kg}$ feed $)$. Meanwhile, no significant differences $(\mathrm{P}>0.05)$ were observed between treatment A ( $2 \mathrm{~g} / \mathrm{kg}$ feed $)$ and B $(3 \mathrm{~g} /$ $\mathrm{kg}$ feed). The increase in respiratory burst was correlated with the increase in phagocytic activity and vice versa (Jasmanindar, 2009; Sirirustananun et al., 2011).

Immune responses such as total hemocytes, phagocytic activity, phenoloxidase activity, and respiratory burst in treatment $\mathrm{D}$ did not significantly differ to those of treatment $\mathrm{K}+$, indicating that immunosuppression occurred in treatment at a dose of $5 \mathrm{~g} / \mathrm{kg}$ feed. Hai (2015) stated that an overdose of immunostimulant could lead to immunosuppression without side effects, but help in decreasing mortality due to diseases. A high dose could not increase the immune response but inhibit it. No positive correlation was noticed between immunostimulant effects and the used doses. Treatment $\mathrm{C}$ ( $4 \mathrm{~g} / \mathrm{kg}$ feed $)$ had the best immune response compared to other treatments, while treatments $\mathrm{A}(2 \mathrm{~g} / \mathrm{kg}$ feed $)$ and $\mathrm{B}(3 \mathrm{~g} / \mathrm{kg}$ feed) were able to trigger the immune system which was less effective compared to treatment $\mathrm{C}(4 \mathrm{~g} / \mathrm{kg}$ feed $)$. The supplementation of immunostimulant has to pay close attention to the optimal doses to be used (Hai, 2015) due to the fact that hgher doses can suppress the defense mechanism, while lower doses can be less effective or not enough in triggering an immune response.

Mortality post challenge test in treatments A ( $2 \mathrm{~g} / \mathrm{kg}$ feed), B ( $3 \mathrm{~g} / \mathrm{kg}$ feed), and C (4 g/kg feed) significantly differed to that of the positive control, indicating that G. verrucosa extract supplementation in shrimp was able to control white spot disease. Treatment $\mathrm{C}$ ( $4 \mathrm{~g} / \mathrm{kg}$ feed $)$ provided the best protection of Pacific white shrimp, which was followed by the highest RPS (in treatment $\mathrm{D}$ ) that was significantly different $(\mathrm{P}<0.05)$ to other treatments. Treatment $\mathrm{C}(4 \mathrm{~g} / \mathrm{kg}$ feed) was the best dose in increasing Pacific white shrimp against WSSV and this was supported by the fact that treatment $\mathrm{C}$ had the best immune system increment as well. In previous research, Gracilaria sp. supplemented to shrimp was able to stimulate both cellular and humoral immune system post-WSSV infection.

G. verrucosa extract contains sulfated galactan that can stimulate the immune system and has an antiviral activity in Pacific white shrimp infected by WSSV. Wongprasert et al. (2013) stated that sulfated galactan with the ability to stimulate the immune system of shrimp was likely mediated by the presence of interactions between sulfated galactan and receptors at the surface of hemocytes. The presence of a relationship between sulfated galactan and the mentioned receptors will activate the signaling process of increasing the proliferation of hemocytes and the stimulation of immune system activity.

Li and Xiang (2013) stated that the receptors in shrimp, i.e. pattern recognition receptors (PRRs) 
play important roles in shrimp immune system and consist of lipopolysaccharide, $\beta$-1,3-glucan binding protein (LGBP) and toll receptors. The introduction of pathogens by PRRs is triggered by the activation through serine protease pathway and finally broken down into proPO in order to produce phenoloxidase. Sulfated galactan in $G$. verrucosa extract consisting of $\beta$-1,3-glucan interacts with LGBP in hemocytes membrane that will activate phenoloxidase enzyme.

Another receptor that plays an important role in the immune system of shrimp is toll-like receptors (TLRs). Wongprasert et al. (2013) supported that sulfated galactan that binds to TLRs is able to regulate the antioxidant enzyme system and eliminate the excess of reactive oxygen species (ROS) while disturbing the replication of the virus in host cells.

\section{CONCLUSION}

The $4 \mathrm{~g} / \mathrm{kg}$ feed dose of $G$. verrucosa extract resulted in the best outcomes in preventing WSSV with RPS of $41.07 \%$ and also the best immune response in shrimp infected with WSSV.

\section{ACKNOWLEDGEMENTS}

The authors would like to thank the Ministry of Research, Technology, and Higher Education Republic of Indonesia which has helped fund this study and the Aquatic Organism Health Laboratory in the Department of Aquaculture, Faculty of Fisheries and Marine Sciences, Bogor Agricultural University which have helped and supported us in completing this study.

\section{REFERENCES}

Amparyup P, Charoensapsri W, Tassanakajon A. 2013. Prophenoloxidase system and its role in shrimp immune responses against major pathogens. Fish and Shellfish Immunology 34: 990-1001.

Anggadiredja JT, Achmad Z, Heri P, Sri I. 2006. Rumput Laut. Jakarta: Penebar Swadaya.

Costa AM, Buglione CC, Bezerra FL, Martins PCC and Barracco MA. 2009. Immune assessement of farm-reared Penaeus vannamei shrimp naturally infected by IMNV in NE Brazil. Aquaculture 291: 141-146.

Febriani D, Sukenda, Nuryati S. 2013. Kappacarrageenan as immunostimulant to control infectious myonecrosis (IMN) disease in white shrimp Litopenaeus vannamei. Jurnal Akuakultur Indonesia 12:77-85.

Garcia-Carreno FL, Cota K and Navarrete del Toro MA. 2008. Phenoloxidase activity of hemocyanin in whiteleg shrimp Penaeus vannamei: conversion, characterization of catalytic properties, and role in postmortem melanosis. Journal of Agricultural and Food Chemistry 56: 6454-6459.

Hai NV. 2015. The use of medicinal plants as immunostimulants in aquaculture: a review. Aquaculture 446: 88-96.

Jasmanindar Y. 2009. Used of Gracilaria verrucosa extract to increase white shrimp Litopenaeus vannamei defenses system [Thesis]. Bogor (ID): Sekolah Pascasarjana, Institut Pertanian Bogor.

Li F, Xiang J. 2013. Signaling pathways regulating innate immune responses in shrimp. Fish and Shellfish Immunology 34: 973-980.

Lin YC, Yeh ST, Li CC, Chen LL, Cheng A, Chen J. 2011. An immersion of Gracilaria tenuistipitata extract improves the immunity and survival of white shrimp Litopenaeus vannamei challenged with white spot syndrome virus. Fish and Shellfish Immunology 31: 1239-1246.

Muiswinkel WBV, Pilarczyk A. 2015. Polish scientists in fish immunology: a short history. Biology 4: 735-755.

Rodriguez J, Moullac GL. 2000. State of the art of immunological tools and health control of penaeid shrimp. Aquaculture 191: 109-119.

Siregar AF, Sabdono A, Pringgenies D. 2012. Potensi antibakteri ekstrak rumput laut terhadap bakteri penyakit kulit Pseudomonas aeruginosa, Staphylococcus epidermidis, dan Micrococcusluteus. Journal of Marine Research 1: 152-160.

Sirirustananun N, Chen JC, Lin YC, Yeh ST, Liou CH, Chen LL, Sim SS, Chiew SL. 2011. Dietary administration of a Gracilaria tenuistipitata extract enhances the immune response and resistance against Vibrio alginolyticus and white spot syndrome virus in the white shrimp Litopenaeus vannamei. Fish and Shellfish Immunology 31: 848-855.

Wang HC, Hao-Ching W, Guang-Hsiung K, ChuFang L, dan Wei-Pang H. 2007. Identification of Icp11, the most highly expressed gene of shrimp white spot syndrome virus (WSSV). Diseases of Aquatic Organisms. 74: 179-89.

Wongprasert K, Rudtanatip T, Praiboon J. 2013. Immunostimulatory activity of sulfated 
galactans isolated from the red seaweed Gracilaria fisheri and development of resistance against white spot syndrome virus (WSSV) in shrimp. Fish and Shellfish Immunology 36: 52-60.

Xu D, Liu W, Alvarez A, Huang T. 2014. Cellular immune responses against viral pathogens in shrimp. Developmental and Comparative Immunology 47: 287-297.

Yao D, Ruan L, Shi H. 2015. Identification of a c-Jun homolog from Litopenaeus vannamei as a downstream substrate of JNK in response to WSSV infection. Developmental and Comparative Immunology 49: 282-289. 